\title{
IgM response against amyloid-beta in aging: a potential peripheral protective mechanism
}

\author{
Sudhanshu Agrawal', Edsel M. Abud², Shikha Snigdha² and Anshu Agrawal ${ }^{1 *}$ (D)
}

\begin{abstract}
Background: The immune system plays a major role in the pathogenesis of age-related dementia, including Alzheimer's disease (AD). An insight into age-associated changes in the immune response to amyloid-beta (A $\beta$ ) in individuals without $A D$ may be beneficial in identifying mechanisms preventing accumulation of $A \beta$.

Methods: We examined the response of human monocyte-derived dendritic cells (DCs), T cells, and peripheral blood mononuclear cells (PBMCs) from healthy aged and young subjects to A $\beta$ peptide 1-42, A $\beta$ fibrils, and recombinant, nonaggregated tau-4 protein with a view to understand the role of peripheral immunity in AD.
\end{abstract}

Results: Our studies revealed that DCs from healthy aged subjects display weak reactivity towards the A $\beta$ peptide and no reactivity towards $A \beta$ fibrils and tau compared with their young counterparts. An analysis of old and young PBMCs revealed that there is no significant T-cell memory against $A \beta$ peptide, fibrils, or tau. Remarkably, the plasma levels of IgM antibodies specific to A $A$ peptide 1-42 were significantly increased in aged subjects compared with young subjects, while IgG levels were comparable. $A \beta$ peptide-specific $\lg M$ and $\lg G$ levels were also determined in the plasma of $A D$ subjects compared with age-matched controls to demonstrate that the immune response against $A \beta$ is stronger in $A D$ patients. $A$ decline in $A \beta$ peptide-specific lgM antibodies was observed in AD patients compared with age-matched controls. In contrast, the levels of IgG as well as interleukin-21, the major cytokine involved in class switching, were increased in $A D$ and patients with mild cognitive impairment, indicating a strong immune response against $A \beta$.

Conclusions: Collectively, low immunogenicity of $A \beta$ in healthy controls may prevent inflammation while the generation of specific IgM antibodies may help in the clearance of $A \beta$ in healthy subjects.

Keywords: Dendritic cells, Amyloid beta, Human, IgM antibody

\section{Background}

Aging is one of the most important risk factors for developing dementia, including Alzheimer's disease (AD) $[1,2]$. One of the hallmark pathologies of late-onset sporadic $\mathrm{AD}$ is extracellular deposits of amyloid beta $(A \beta)$ peptides [3-5]. A $\beta$ accumulations, as well as other insults in the brain, are a natural part of the aging process [6]. In $A D$, increased $A \beta$ deposits compromise the immune function and clearance in a cyclic manner. Monomeric $A \beta$ can self-aggregate to form oligomers,

\footnotetext{
*Correspondence: aagrawal@uci.edu

'Division of Basic and Clinical Immunology, Department of Medicine,

University of California, Irvine, Irvine, CA 92697, USA

Full list of author information is available at the end of the article
}

protofibrils, and amyloid fibrils which deposit as amyloid plaques. One hypothesis is that increased levels of $A \beta$ leads to the hyperphosphorylation of the microtubule-associated protein tau, which results in formation of neurofibrillary tangles and accumulation of tau in some forms of $A D$ $[7,8]$. In addition to forming plaques and tangles, $A \beta$ and tau can be recognized by pattern recognition receptors found on astrocytes and microglia/macrophages, and trigger an immune response characterized by release of inflammatory mediators which can increase $A \beta$ production in a cyclic manner [9]. Furthermore, the increased inflammatory response also triggers peripheral inflammation. A significant body of evidence supports the hypothesis that increased peripheral inflammation can lead to increased

(C) The Author(s). 2018 Open Access This article is distributed under the terms of the Creative Commons Attribution 4.0 International License (http://creativecommons.org/licenses/by/4.0/), which permits unrestricted use, distribution, and 
neurodegeneration and may be a key driver of accelerated disease progression in $\mathrm{AD}$ [10]. Recent evidence from genomic studies has highlighted the role of the immune system in the etiology of AD [11-13]. Both the innate and adaptive immune responses have been implicated.

Though advancing age is the major risk factor for AD, it is not clear why certain aged individuals are more efficient at clearing $A \beta$ and preventing neuroinflammation. Differences in the immune responses to $A \beta$ between $A D$ patients and healthy controls may be one of the factors. However, age-associated changes in the immune response to $A \beta$, which is a self-antigen, remains a relatively unexplored area of research. This is especially important since advancing age significantly impacts innate and adaptive responses which alter the response to both self and foreign antigens. Previous studies from our laboratory have demonstrated that the functions of important immune cells, dendritic cells (DCs), are substantially altered with age and play a role in enhancing peripheral inflammation [14-17]. DCs play a major role in innate immunity and have important functions in the phagocytosis of pathogens and cell debris [18]. DCs sense and respond to pathogens and endogenous danger signals by upregulating the antigen-presenting markers MHCII and costimulatory markers, as well as by secreting proinflammatory cytokines and priming T-cell responses. DC numbers have been reported to be increased in the brains of aged mice [19] while the percentage of DCs in the periphery is reported to be comparable between aged and young mice and humans $[14,20]$. However, DCs from aged subjects display enhanced proinflammatory cytokines, such as tumor necrosis factor (TNF)- $\alpha$ and interleukin (IL)-6 secretion in response to Toll-like receptor (TLR)4 ligand and lipopolysaccharide (LPS), while the secretion of the anti-inflammatory cytokine IL-10 is impaired [14, 16]. Furthermore, we have also observed enhanced DC responses against self-antigens in the elderly [15]. The effect of age on T-cell responses has been studied more extensively. A decline in naive $T$ cell numbers and regenerative capacity as well as a decrease in the diversity of the T-cell repertoire are a hallmark of aging $[21,22]$. The numbers of naive and memory $\mathrm{CD}^{+} \mathrm{T}$ cell numbers are intact but there is an accumulation of $\mathrm{CD} 4^{+} \mathrm{CD} 28^{-}$cells [21]. Furthermore, aging also impairs $\mathrm{B}$ cell number and function. Although the overall antibody production is reduced, there is increased production of low-affinity antibodies due to decreased isotype switching [23]. Altogether, these factors have a significant impact on the immunity of the aged individuals which may play a role in the development and progression of $\mathrm{AD}$.

A clearer understanding of the immune response changes in aged individuals without AD will be helpful in identifying mechanisms that lead to production or clearance of $\mathrm{A} \beta$. We therefore investigated age-associated changes in the response of monocyte-derived DCs as well as the T-cell memory and B-cell antibody response to $A \beta$ peptide 1-42 (A $\beta 42)$ from aged subjects. $A \beta 42$ is the most amyloidogenic form of the peptide according to the amyloid cascade hypothesis.

\section{Methods \\ Aged and young blood donors}

Peripheral blood samples were obtained from healthy aged and young volunteers. The young donors were aged between 20 and 35 years. Healthy aged donors were aged between 60 and 90 years. Subjects were recruited by the Institute of Clinical and Translational Science (ICTS), UC Irvine. Blood was drawn by research-trained nurses. The elderly subjects have a middle-class socioeconomic status and are living independently. Subjects suffering from diseases such as diabetes and heart disease or those on long-term medications as well as those taking drugs that can affect the immune system were excluded from the study. The number of subjects used for the different experiments differs since serum samples were available for more subjects than those used for cell-based experiments. The number of samples used for each experiment is specified in the figure legends. The inclusion and exclusion criteria of subjects for both types of experiment were the same. A description of the cohort is provided in Table 1 and includes samples for both serum and cellular experiments. This study was approved by the Institutional Review Board of the University of California, Irvine (UCI), and subjects provided their consent for the study.

\section{Serum samples from patients and controls}

De-identified serum samples from $\mathrm{AD}$ patients and patients with mild cognitive impairment (MCI), as well as age- and sex-matched healthy controls $(\mathrm{HC})$, were obtained from the Alzheimer's Disease Research Center

Table 1 Description of aged and young cohorts

\begin{tabular}{lll}
\hline & Young & Aged \\
\hline Number of subjects $(n)$ & 50 & 50 \\
Age range (years) & $20-37$ & $66-95$ \\
Mean age (years) & 26 & 78 \\
Gender ( $n)$ & & \\
$\quad$ Male & 23 & 12 \\
$\quad$ Female & 27 & 38 \\
Comorbidities $(n)$ & & \\
$\quad$ Osteoarthritis & & 28 \\
$\quad$ Hypertension & & 14 \\
Dyslipidemia & & 6 \\
Medications $(n)$ & & 48 \\
\hline
\end{tabular}


(ADRC) core at UCI. The ADRC at UC Irvine is one of the 30 centers funded by the National Institutes of aging (NIA). The physicians in the Clinical Core of ADRC evaluate people with and without cognitive problems using the Clinical Dementia Rating (CDR) scale. Subjects are evaluated at least annually using neurological and physical examination and neuropsychological assessment. Brain imaging (positron emission tomography (PET) and magnetic resonance imaging (MRI)) is also performed to detect lesions. Amyloid levels in the cerebrospinal fluid (CSF) as well as blood and diagnostic tests are performed for diagnosis. In addition, an interview with a study partner is also conducted. The subjects are followed at least annually until death to document the normal and pathological brain changes as well as progression of the disease. Table 2 provides the description of the samples.

\section{DC generation and activation}

Monocyte-derived DCs were prepared as previously described [15]. Briefly, purified monocytes from the aged and young individuals were cultured with granulocyte/ macrophage colony-stimulating factor (GM-CSF) and IL-4 (PeproTech, NJ) for 6 days as previously described $[15,24]$. Differentiated DCs were characterized as $\mathrm{CD} 14^{-}, \mathrm{CD} 11 \mathrm{c}^{+}$, and HLA-DR ${ }^{+}$using flow cytometry after 6 days, indicating successful differentiation to DCs. Immature DCs from aged and young subjects were subsequently stimulated with $A \beta 42$ (Tocris), $A \beta$ fibrils (a kind gift from Dr. Blurton-Jones), recombinant human Tau protein (1 to 441) (Abcam; ab199583), nonaggregated isoform-F in serum-free AIM-V medium (ThermoFisher). A $\beta$ fibrils were generated and characterized as previously described [25]. Briefly, the $A \beta$ peptide was first dissolved in $\mathrm{NH}_{4} \mathrm{OH}(0.1 \%)$ to $1 \mathrm{mg} / \mathrm{ml}$ and then further diluted to $100 \mu \mathrm{g} / \mathrm{ml}$ using sterile endotoxin-free water, vortexed thoroughly, and incubated at $37{ }^{\circ} \mathrm{C}$ for 7 days. $\mathrm{A} \beta$ fibril conformation was

Table 2 Description of the Alzheimer's disease (AD), mild cognitive impairment $(\mathrm{MCl})$, and healthy control $(\mathrm{HC})$ cohorts

\begin{tabular}{llll}
\hline & $\mathrm{AD}$ & $\mathrm{MCl}$ & $\mathrm{HC}$ \\
\hline Number of subjects $(n)$ & 26 & 26 & 26 \\
Age range (years) & $75-87$ & $74-86$ & $75-85$ \\
Mean age (years) & 79.6 & 79.6 & 79.3 \\
Gender ( $n$ ) & & & \\
$\quad 13$ & 13 & 13 \\
$\quad$ Male & 13 & 13 & 13 \\
$\quad$ Female & $6-25$ & $21-30$ & $27-30$ \\
MMSE score (range) & $17.93 \pm 5.5$ & $27.5 \pm 2.4$ & $29.6 \pm 0.8$ \\
MMSE score (mean \pm SD) & $4.5-13$ & $0.5-4.5$ & $0-0.5$ \\
CDR (range) & $8 \pm 3.1$ & $1.97 \pm 1.3$ & $0.07 \pm 2.1$ \\
CDR (mean \pm SD) &
\end{tabular}

CDR Clinical Dementia Rating, MMSE Mini-Mental State Examination, $S D$ standard deviation verified via dot-blot and using conformation-specific antibodies as previously described [25]. The A $\beta$ fibrils were mixed thoroughly before addition to cells. We cannot rule out that the preparation may contain some oligomers. Optimal activation of DCs was observed at $10 \mu \mathrm{g} / \mathrm{ml}$ concentration of these peptides. After overnight stimulation, supernatants were collected and assayed for IL-6, IL-1 $\beta$, C-X-C motif chemokine 10 (CXCL-10), C-C motif chemokine ligand (CCL)-2 (BD Biosciences, San Jose, CA), and CCL-4 (R\&D Systems) using specific enzyme-linked immunosorbent assays (ELISAs). A disintegrin and metalloproteinase domain (ADAM) 12 was assayed by an ELISA kit from R\&D Systems while brain-derived neurotrophic factor (BDNF) was assessed by a specific ELISA from Biosensis.

\section{DC and $T$ cell coculture}

Stimulated DCs $\left(2 \times 10^{4}\right)$ were cultured with purified, naive, allogeneic T cells $\left(1 \times 10^{5}\right)$ from young donors at a ratio of 1:5 for 6 days. Naive CD4 T cells were isolated by negative selection using a magnetic bead-based kit (Stemcell Technologies). The purity of the naive T-cell $\left(\mathrm{CD}^{+}, \mathrm{CD}^{2} 5 \mathrm{RA}^{+}, \mathrm{CCR}^{+}\right)$preparation was confirmed with flow cytometry. DC/T-cell supernatant was collected and assayed for interferon (IFN) $-\gamma$, TNF- $\alpha$, IL-10 (BD Biosciences), and IL-17 (R\&D Systems) using specific ELISAs.

\section{PBMC stimulation}

Peripheral blood mononuclear cells (PBMCs) from aged and young subjects were stimulated with $\mathrm{A} \beta 42$ in serumfree AIM-V medium for 6 days. Supernatants were collected and assayed for IFN- $\gamma$, TNF- $\alpha$, IL-10, and IL-17 using specific ELISAs.

\section{$A \beta$ antibody assay}

Previously collected plasma samples from aged and young subjects and serum samples from $\mathrm{AD}, \mathrm{MCI}$, and age-matched controls were assayed for the presence of A 342 -specific antibodies using an in-house ELISA which was based on a previously published assay by Qu et al. [26]. Briefly, ELISA (Maxisorp) plates were coated with $2 \mu \mathrm{g} / \mathrm{ml}$ human $\mathrm{A} \beta 42$ peptide in a $0.1 \mathrm{M}$ bicarbonate-carbonate buffer (pH 9.0) at $4{ }^{\circ} \mathrm{C}$ overnight $(100 \mu \mathrm{l} /$ well). The wells were then blocked with $100 \mu \mathrm{l}$ \% bovine serum albumin (BSA) in phosphate-buffered saline (PBS) for $1 \mathrm{~h}$ and then washed three times with PBST (PBS containing 0.05\% (v/v) Tween-20). Then, $100 \mu \mathrm{l}$ of plasma (diluted 1:5 with blocking buffer) was added to the plates and incubated at room temperature for $2 \mathrm{~h}$. The plates were then washed three times with PBST and incubated for 2 $\mathrm{h}$ at room temperature with the secondary antibody conjugated to streptavidin (eBioscience) at a 1:1000 dilution in 1\% BSA-PBST. The plates were then washed 
five times with PBST and incubated with streptavidin HRPO (eBioscience, 1:1000) for 30 mins. After washing, a $100-\mu$ l solution of 3,3,5,5-tetramethylbenzidine (TMB) was added to the wells to form a colored reaction product indicating the presence of anti-A $\beta$ antibodies. The reaction was stopped by adding $2 \mathrm{~N}$ sulfuric acid and absorbance was measured at a wavelength of $450 \mathrm{~nm}$ with a plate reader. To determine the specificity of binding of antibodies to the $A \beta$ peptide, a scrambled peptide of $A \beta$ (a randomly scrambled amino-acid sequence of $A \beta 42$ peptide) was used as a control. The binding to the scrambled peptide was a measure of nonspecific binding. The values were calculated as a ratio of absorbance to $A \beta$ peptide and scrambled peptide. Ratios above one were considered positive.

\section{Statistical analysis}

Statistical analysis was performed using GraphPad Prisms software. Data were checked for normality, and significance within groups was measured by $t$ tests. The unpaired $t$ test was used to measure significance between aged and young subjects. Values of $p<0.05$ were considered significant. For comparison between three or more groups, one-way analysis of variance (ANOVA) followed by Tukey's test was used. All tests were two tailed with $95 \%$ confidence intervals.

\section{Results}

$D C s$ from aged subjects are weakly reactive to $A \beta$ peptide

Aging significantly impacts DC phenotype and functions such as antigen presentation and chemokine/cytokine secretion. We compared the response of DCs from healthy aged and young subjects to $A \beta 42$ ( $A \beta$ peptide) to examine the role of $\mathrm{DCs}$ in $\mathrm{AD}$ disease progression. Supernatants of $A \beta$-stimulated DCs from an initial three experiments were screened with a multiplex kit detecting thirty different chemokines and cytokines. In addition, we also determined the levels of ADAM12 and BDNF as these are both secreted by DCs and are involved in $\operatorname{AD}[27,28]$. A response to $A \beta$ was only observed for CXCL-10, CCL-4, CCL-2, IL-6, and IL-1 $\beta$ (Additional file 1: Figure S1). Subsequent experiments revealed that DCs from aged subjects exhibited significantly increased secretion of CXCL-10 $(p=0.04)$, CCL-4 $(p=0.02)$, and IL-6 $(p=0.01)$ in response to $A \beta$ peptide relative to DCs from young subjects (Fig. 1). The levels of IL-1 $\beta$ and CCL-2 secreted were not significantly different between aged and young DCs.

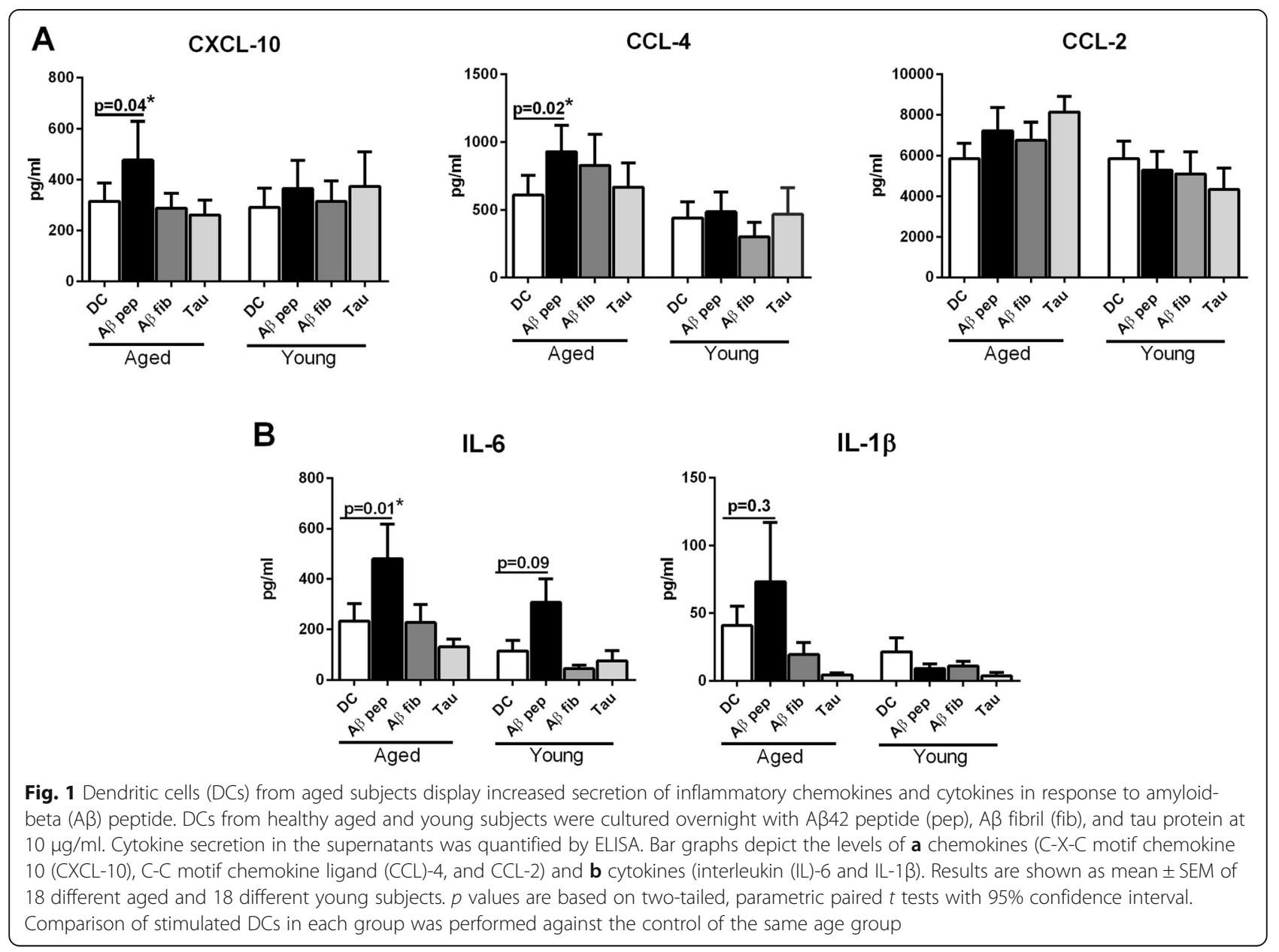


In addition to $A \beta$ peptide, we also compared the response of DCs from aged and young subjects to $A \beta$ fibril and tau proteins. However, no significant difference in chemokine or cytokine levels was observed with $A \beta$ fibril and tau (Fig. 1). Taken together, these results demonstrate that DCs from healthy aged subjects are weakly responsive and generate a low-level mild chemokine response to $A \beta$ peptide compared with DCs from young subjects.

\section{$A \beta$ peptide-activated $D C$ s from aged subjects do not prime CD4 T cells to secrete cytokines}

Cytokines and chemokines secreted by DCs dictate the polarization of T-helper cell responses towards Th1/ Th2/Treg/Th17 T-cell subtypes and their secretion of inflammatory cytokines. Therefore, we determined the effect of $\mathrm{A} \beta$ peptide on CD4 T-helper cell differentiation by aged and young DCs. Purified, naive CD4 T cells from young subjects (to exclude any T-cell defect) were cultured along with aged and young DCs stimulated with the aforementioned peptide. Cytokine secretion by $\mathrm{T}$ cells was quantified from culture media using ELISA. Secretion of TNF- $\alpha$, IFN- $\gamma$, IL-17, and IL- 10 by T cells was not significantly different between stimulated and unstimulated DCs in both age groups (Fig. 2). In summary, these data indicate that $A \beta$ peptide-, $A \beta$ fibril-, and tau-activated DCs from aged subjects do not induce significant priming of CD4 T cells. This is in keeping with the poor response of DCs from aged subjects to $A \beta$ peptide observed in Fig. 1.

\section{$A \beta$ peptide does not induce $T$ cell cytokine secretion from PBMCs of aged and young subjects}

To confirm that the poor CD4 T-cell priming observed above is not an artifact of in-vitro coculture, we determined whether $A \beta$-specific memory $T$ cells were present in aged subjects. The generation and persistence of memory $\mathrm{T}$ cells would indicate a pre-existing efficient immune response to $A \beta$ strong enough to generate T-cell memory for subsequent encounters. To investigate this, PBMCs from
TNF- $\alpha$

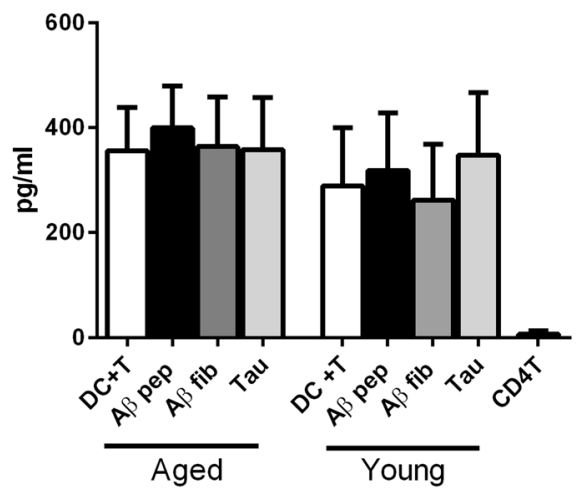

IL-17

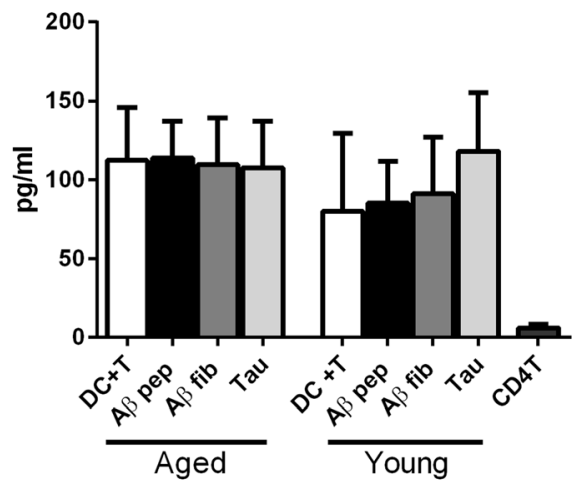

IFN- $\gamma$

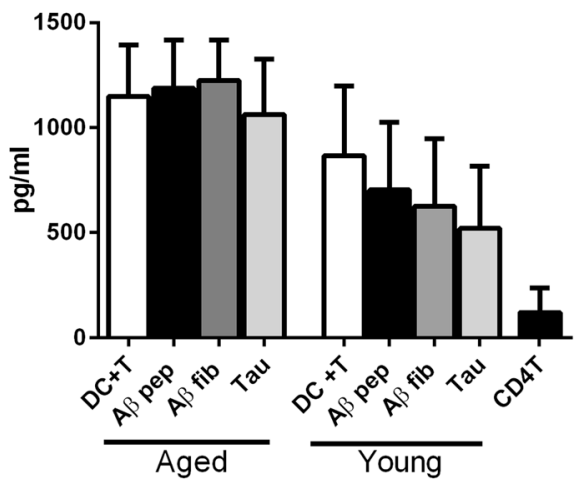

IL-10

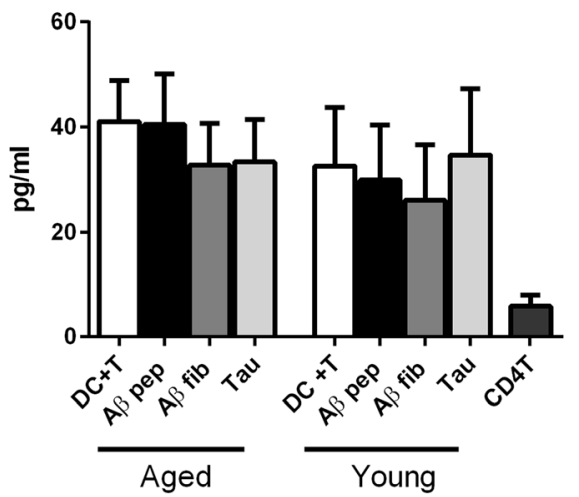

Fig. 2 Amyloid-beta (AB) activates dendritic cells (DCs) from aged subjects which prime CD4 T cells to secrete tumor necrosis factor (TNF)-a. A 42 peptide (pep)-, A $\beta$ fibril (fib)-, and tau protein-exposed DCs from aged and young subjects were cultured with purified CD4 T cells for 6 days. Bar graphs depict the level of the cytokines TNF-a, interferon (IFN)- - , interleukin (IL)-17, and IL-10 in the supernatants after 6 days as determined by specific ELISA. Results are shown as mean \pm SEM of 14 different aged and 14 different young subjects. $p$ values are based on two-tailed, parametric paired $t$ tests with $95 \%$ confidence interval. Comparison of stimulated DCs in each group was performed against the control of the same age group 
aged and young subjects were stimulated with $A \beta$ peptide for 6 days to reactivate any potential memory T cells. Supernatants collected were assayed for TNF- $\alpha$, IFN- $\gamma$, IL-10, and IL-17 as a measure of T-cell activation. Stimulation with $A \beta$ did not induce secretion of the cytokines above those with the unstimulated PBMCs in either aged or young subjects suggesting that the numbers of memory $T$ cells to $A \beta$ are either very low or absent in both populations (Fig. 3). We did observe significantly increased $(p<0.05)$ secretion of IFN- $\gamma$ and TNF- $\alpha$ from unstimulated PBMCs of aged subjects compared with young subjects, which is in line with the enhanced inflammatory state of aged subjects as previously reported [24].

\section{A 342 peptide-specific antibodies of IgM isotype are increased in aged subjects}

Next, we determined whether there is a change in $A \beta$ antibody levels with age. We assayed the levels of both IgG and IgM isotypes of antibodies against $A \beta 42$ in the plasma from males and females of aged and young subjects using an in-house ELISA. The IgM class was assayed because we did not observe a T-cell memory response in PBMCs of aged and young subjects; thus, it was possible the T-cell-independent IgM antibodies may be affected by age. An increase in natural autoantibodies of the IgM class has been reported with age $[29,30]$. The presence of $A \beta$-specific antibodies were assayed using an in-house ELISA. As shown in Fig. 4a, we observed a tendency towards a decrease in A $\beta$-specific IgG antibodies $(p=0.06)$ in the aged subjects compared with the young subjects. In contrast, there was a significant increase in $A \beta$-specific IgM antibodies in the aged subjects $(p=0.02)$. Genderbased analysis revealed that the A $\beta$-specific IgG antibody levels were similar in both males and females of aged and young subjects. However, IgM levels were significantly higher $(p=0.02)$ in aged females compared with young females while no significant difference was observed in males (Fig. 4b). Altogether, these results indicate that low-affinity antibodies of IgM against $A \beta$ are increased with age, particularly in females.

\section{IFN- $\gamma$}

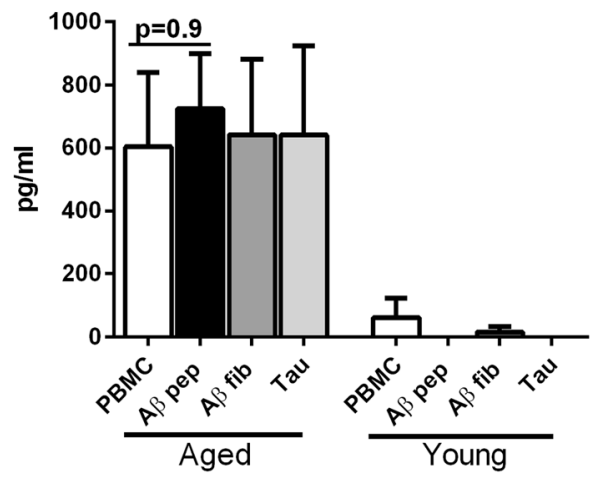

IL-10

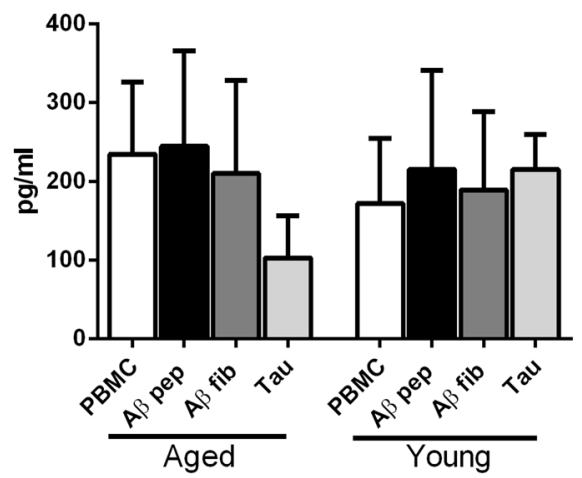

TNF- $\alpha$

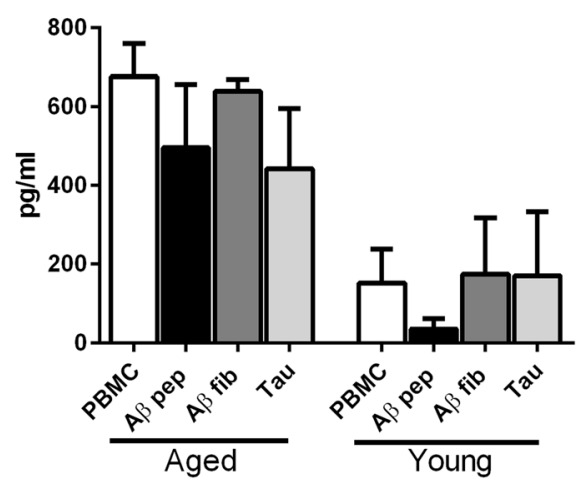

IL-17

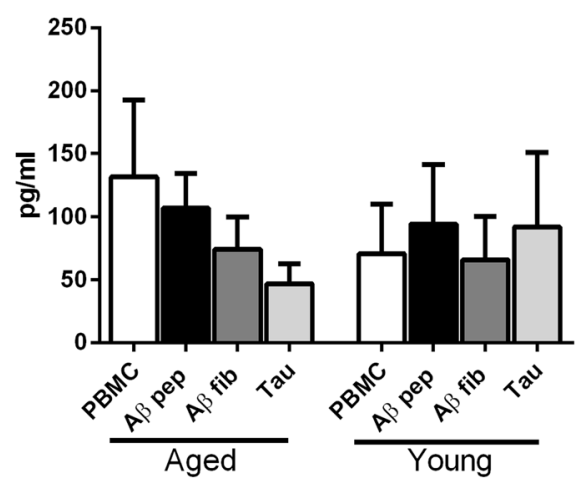

Fig. 3 Amyloid-beta (Aß) peptide does not induce T cell cytokine secretion from peripheral blood mononuclear cells (PBMCs) of aged and young subjects. PBMCs from aged and young subjects were stimulated with Aß42 peptide (pep) for 6 days. Bar graphs depict the level of the cytokines tumor necrosis factor (TNF)- $a$, interferon (IFN)- $\gamma$, interleukin (IL)-17, and IL-10 in the supernatants after 6 days as determined by specific ELISA. Results are shown as mean \pm SEM of 6 different aged and 6 different young subjects. $p$ values are based on two-tailed, parametric paired $t$ tests with $95 \%$ confidence interval. Comparison of stimulated DCs in each group was performed against the control of the same age group. fib fibril 

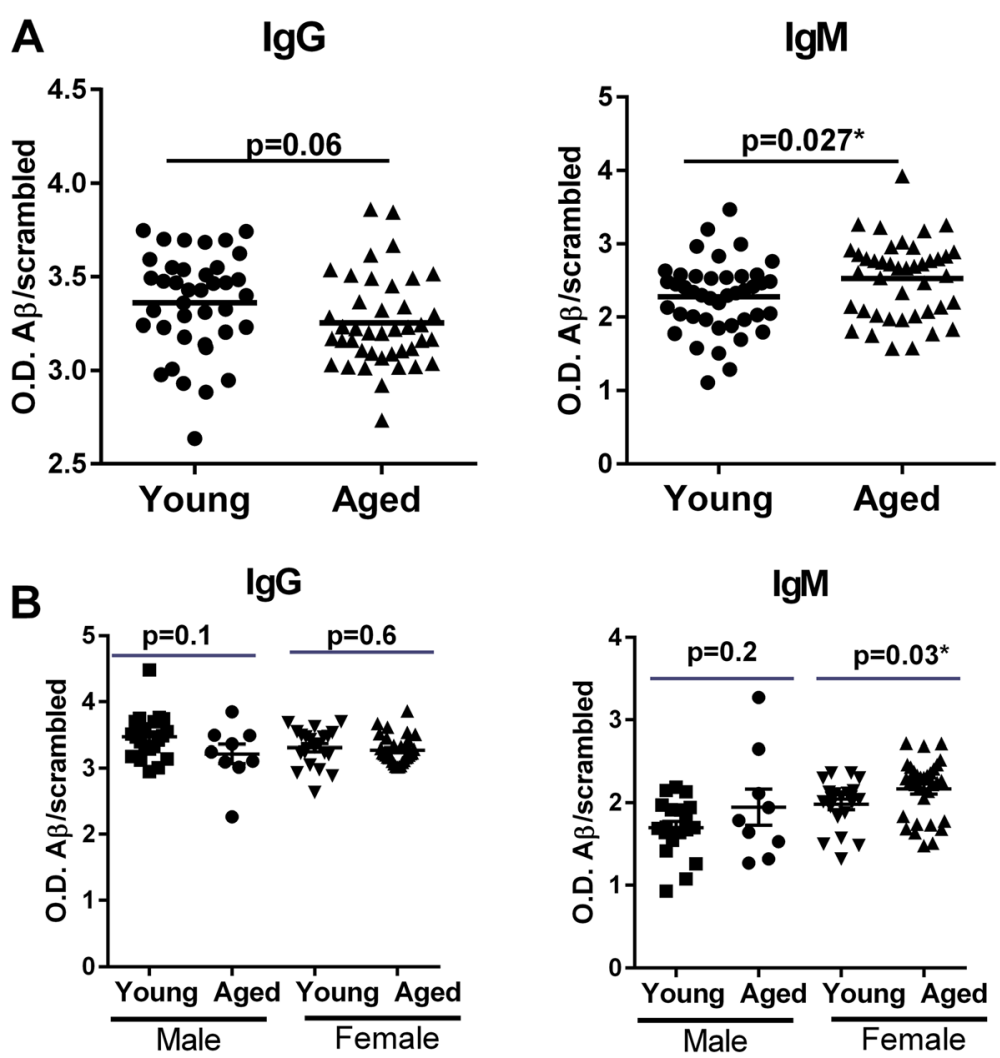

Fig. 4 Amyloid-beta $(A \beta) 42$ peptide-specific antibodies of IgM isotype are increased in aged subjects. The levels of A 42 -specific antibodies as well as A $\beta$ scrambled peptide were measured from the plasma samples of aged and young subjects using an in-house ELISA. a Dot plots depict the ratio of $A \beta$-specific $\lg G$ and IgM antibodies to scrambled peptide antibodies. Results are shown as mean \pm SD of 43 different aged and 43 different young subjects. $\mathbf{b}$ Dot plots depict the ratio of A 42 -specific lgG and IgM antibodies to scrambled peptide antibodies in male and female aged and young subjects. Results are shown as mean \pm SD of 9 aged males and 20 young males and 34 aged females and 23 young females. $p$ values are based on two-tailed, unpaired $t$ tests with $95 \%$ confidence interval. O.D. optical density

\section{$A \beta 42$ peptide-specific antibodies of IgM isotype are decreased in AD patients}

If the increased levels of $A \beta$-specific IgM antibodies observed in aged subjects are assumed to be protective, then the levels of these antibodies should be decreased in $\mathrm{AD}$ patients. To confirm this, we determined the levels of A 342 -specific IgM and IgG antibodies in the serum samples from AD and MCI patients as well as age- and sex-matched healthy controls obtained from the ADRC core at UCI. As shown in Fig. 5, the level of IgM antibodies was significantly decreased in the serum of $\mathrm{AD}$ patients versus the healthy controls $(p=0.0023)$. MCI patients also displayed a tendency towards decreased levels of IgM compared with healthy controls, but the difference was not significant $(p=0.065)$. The level of IgM antibodies between MCI and AD patients was also not significant. In contrast to IgM, the IgG antibodies displayed a significant increase in both MCI $(p=0.04)$ and $\mathrm{AD}$ patients $(p=0.03)$ compared with the controls.
$\mathrm{T}$ follicular helper (Tfh) cells play a major role in class switching of antibodies from IgM to IgG and other subclasses [31]. The signature cytokine for Tfh cells is IL-21 which acts on B lymphocytes to induce class switching and antibody secretion. Therefore, the level of IL-21 in the serum of control, MCI, and AD patients was assayed using a specific ELISA. Remarkably, we observed a significant increase in the IL-21 levels in the serum of AD patients compared with controls $(p=0.03)$. IL-21 also displayed an increasing trend in MCI patients compared with controls. Since AD prevalence is higher in women [32], data were also analyzed to investigate the effect of gender differences on the levels of IgG and IgM antibodies. No significant differences were observed (data not shown). Thus, both the IgG subclass and IL-21 are increased in AD patients compared with controls.

\section{Discussion}

In this, we examined the immune response of the healthy elderly to $A \beta$. Our results indicate that DCs from healthy 

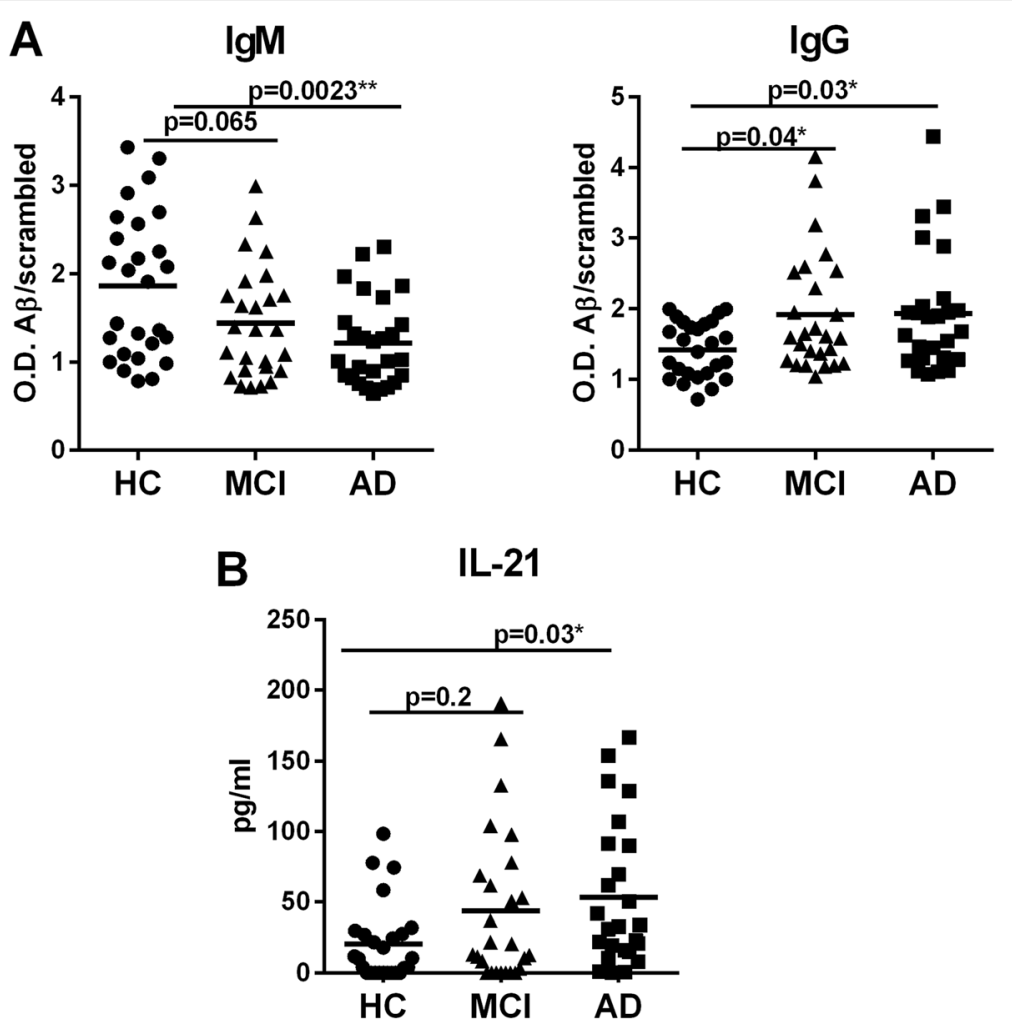

Fig. 5 Amyloid-beta $(A B) 42$ peptide-specific antibodies of IgM isotype are decreased in Alzheimer's disease (AD) patients compared with healthy controls (HC). The levels of A 442 -specific antibodies as well as $A \beta$ scrambled peptide were measured from the plasma samples of AD patients, those with mild cognitive impairment (MCl), and age-matched healthy controls. a Dot plots depict the ratio of A 342 -specific IgG and IgM antibodies to scrambled peptide antibodies. b Dot plot depicts the levels of IL-21 in the same samples. Results are shown as mean \pm SD of 26 AD patients, 26 $\mathrm{MCl}$ patients, and 26 healthy controls. $p$ values are based on one0way ANOVA followed by Tukey's test with two tails and $95 \%$ confidence interval

aged subjects primarily produce chemokines in response to $A \beta$ peptide compared with DCs from young subjects (Fig. 1). One of the reasons for the increased response of $D C s$ from aged subjects to $A \beta$ could be the increased basal level of activation of DCs which increases their reactivity to self-proteins, as observed in our earlier studies [15]. The increased levels of CCL- 4 and CXCL-10 produced by DCs from aged subjects can attract a variety of immune cells including monocytes and natural killer (NK) cells which can help with the clearance of $A \beta$. Furthermore, DCs from healthy aged subjects display only low-level inflammatory responses to $A \beta$ which is beneficial since mild activation of microglia and astrocytes has been reported to have neuroprotective effects and ameliorates early symptoms of neurodegeneration [33]. Previous studies have compared the response of DCs from AD subjects with healthy aged controls to $A \beta$ and observed an increased inflammatory response in the $\mathrm{DCs}$ from $\mathrm{AD}$ subjects [27]. They also observed a decrease in the secretion of BDNF by DCs from AD subjects compared with controls. We did not observe induction of BDNF by $A \beta$ in our studies (Additional file 1: Figure S1) in either age groups. One reason for this discrepancy could be due to difference in stimulatory conditions since, in the previous study, the DCs were stimulated in the presence of GM-CSF and IL-4 (factors used for DC differentiation). In contrast to $A \beta$ peptide, $A \beta$ fibrils and tau protein did not activate DCs. The reason for this is not clear, but it is possible that a much higher concentration of these may be required to activate DCs. It may be that the enhanced inflammatory response as reported for $\mathrm{AD}$ subjects is detrimental since high levels of inflammation have been reported to promote the production of $A \beta$ [9].

In keeping with the weak response to $A \beta$, DCs from aged subjects also did not induce cytokine secretion from $\mathrm{T}$ cells (Fig. 2). In contrast, a previous study by Ciaramella et al. $[34,35]$ reported that differentiation of monocytes from healthy subjects to DCs in the presence of $\mathrm{A} \beta 42$ resulted in a decrease in $\mathrm{MHC}$ expression and the ability to activate $\mathrm{T}$ cells. The decrease in $\mathrm{T}$-cell priming by the DCs in this earlier study could be due to different conditions of exposure to $A \beta$ (during differentiation versus already differentiated DCs). DCs isolated from $\mathrm{AD}$ patients and subsequently stimulated with LPS have also been demonstrated to have reduced antigen-presenting ability [34] compared with controls. Reduced priming of T 
cells by DCs from AD patients may enhance the induction of $\mathrm{T}$ regulatory cells (Tregs), which could explain the increased levels of Tregs observed in the periphery of MCI and $\mathrm{AD}$ patients [36]. Induction of Tregs in the periphery has been shown to be detrimental for $\mathrm{AD}$ since transient depletion of Tregs in the circulation ameliorated the brain pathology and reversed cognitive decline in mouse models of AD [37]. Furthermore, myeloid DC numbers are also reported to be decreased in $\mathrm{AD}$ patients [38]; low myeloid DC levels could further decrease the immune response against $A \beta$ in the periphery and prevent its clearance. In light of these observations, we can hypothesize that the low-level reactivity of DCs from healthy aged subjects to $\mathrm{A} \beta$ aids in its clearance and prevents inflammation. However, further studies with $\mathrm{DCs}$ from $\mathrm{AD}$ patients at different stages of the disease need to be performed to draw any conclusions. Also, DCs in the periphery do not represent the brain, and thus the data may represent primarily systemic effects. Further studies using mouse models may be able to correlate brain inflammation with systemic effects. One of the other limitations of the study is the use of high concentrations $(10 \mu \mathrm{g} / \mathrm{ml})$ of $\mathrm{A} \beta 42$. This is higher than the pico/ nano levels observed in the circulation [39]. That being said, the total concentration of all $A \beta 38-42$ peptides may be much higher. Also, the levels in the brain are much higher. We have only examined the reactivity to $A \beta 42$ peptide; $A \beta 40$ is also a highly pathogenic form along with $A \beta 43,38$, and so forth. It would be interesting to compare the immune response against these different forms although, since the peptide sequences are similar, the different $A \beta$ peptides are expected to induce comparable DC responses. Similar response of DCs to hyperphosphorylated tau and tangles may also be different and differ as the disease progresses. Another thing to keep in mind is that this study is a case-control study, and it is not known how these findings will translate to populations where relationships between dementia status and neuropathological change are more complex.

In this study, we also observed an increase in $A \beta$-specific IgM antibodies in the circulation of healthy elderly (Fig. 5) compared with $\mathrm{AD}$ patients, while the level of $\mathrm{A} \beta$-specific IgG antibodies was decreased. The presence of high levels of IgM antibody along with low levels of IgG antibodies also indicates a weak immune response. It suggests that, although the immune response against $A \beta$ is initiated in the healthy controls, it is not strong enough to induce class switching to IgG or the generation of T cell memory [40-42]. Increased levels of IL-21 found in the serum of AD patients also supports this since IL-21 enhances the differentiation of B cells towards antibody-secreting B cells and also helps in class switching of IgM antibodies towards IgG antibodies. Antibodies against self-proteins such as $A \beta$ are called natural antibodies. Natural antibodies are essentially antibodies of the IgM isotype present in the circulation of normal humans and other mammalian species. They are detectable in the serum of healthy individuals before deliberate immunization. They have been found to play an innate-like role in protection against infectious agents and to exert homeostatic functions in a variety of experimental models [43-45]. One of the major homeostatic functions of the natural antibodies is to help in the removal of autoantigens such as $\mathrm{A} \beta$. The IgM isotype is beneficial in this regard as these antibodies have a low affinity against the antigen compared with IgG antibodies. However, their avidity of binding to antigens is high because of their pentameric structure which aids in clearance of the antigens. Natural autoantibodies against $A \beta$ have also been demonstrated to play a protective role in AD. Autoantibodies against $A \beta$ play a role in $A \beta$ clearance and these are lower in $\mathrm{AD}$ patients than controls $[46,47]$. Very recently, a study by Marsh et al. [46] demonstrated that genetically modified AD mice lacking three key immune cell types ( $\mathrm{T}$ cells, B cells, and NK cells) displayed a twofold increase in $\mathrm{A} \beta$ accumulation compared with $\mathrm{AD}$ mice with an intact immune system [46]. They further showed that this is due to a decrease in antibodies as the accumulation of natural antibodies in the brain in immune competent mice helped increase the clearance of $A \beta$. Antibody production thus appears to be beneficial in the fight against $\mathrm{AD}$.

The increased levels of IL-21 observed in AD patients is also indicative of ongoing inflammation since, in addition to B-cell differentiation, IL-21 is also a highly inflammatory cytokine that can enhance the differentiation of IL-17, producing Th17 cells [48]. Both IL-21 and IL-17 have been implicated in numerous inflammatory diseases [30, 31, 48, 49]. For example, high levels of IL-21 have been demonstrated to promote a range of autoimmune diseases, including multiple sclerosis, inflammatory bowel disease, and psoriasis. More recently, IL-21 was found to be highly upregulated in the mouse brain after cerebral ischemia [50]. It is therefore plausible to speculate that IL-21 may play a dual role in the pathogenesis of $\mathrm{AD}$ by enhancing IgG production and by increasing inflammation via Th17 cells. Enhanced production of $A \beta$ and related peptides, fibrils, and tangles in $\mathrm{AD}$ may also act as antigens to induce inflammatory immune responses in addition to causing neurological damage as suggested by the amyloid cascade hypothesis. The presence of $\mathrm{T}$ cells in the brain of $\mathrm{AD}$ patients [46] may be indicative of disruption of the blood-brain barrier due to increased peripheral inflammation. It would be interesting to determine a correlation between IL-21 levels as well as IL-21-producing Tfh cells with disease progression.

\section{Conclusions}

In summary, we demonstrate for the first time that DCs from healthy aged subjects display mild inflammatory 
responses to $A \beta$ in the form of chemokine secretion and low-level T-cell priming which may facilitate clearance of $A \beta$. Furthermore, we also observe enhanced levels of $A \beta$-specific IgM antibodies in the circulation of healthy controls compared with $\mathrm{AD}$ subjects, which may also help clear the $A \beta$. Thus, we describe two novel mechanisms which may be operating in healthy subjects to prevent the development of AD. These data also suggest novel therapeutic strategies using antibodies to clear $A \beta$. In addition, we also observe increased IL-21 in the serum of AD patients, which may serve as a biomarker for immune and inflammatory response in these subjects.

\section{Additional file}

Additional file 1: Factors secreted by DCs after stimulation with $A \beta$. (JPG 63 kb)

\section{Acknowledgements}

We are grateful for UCI-ICTS for providing the blood and to UCI-ADRC for providing the serum samples from AD patients and controls.

\section{Funding}

UCI-MIND pilot grant and NIH grants AG045216 (to AA) and UL1 TR000153 to the National Center for Research Resources and the National Center for Advancing Translational Sciences. The UCI-ADRC is funded by NIH/NIA grant P50 AG16573. The content is solely the responsibility of the authors and does not necessarily represent the official views of the $\mathrm{NIH}$.

\section{Availability of data and materials}

The datasets used and/or analyzed during the current study are available from the corresponding author on reasonable request.

\section{Authors' contributions}

SA performed the DC and DC/T cell experiments as well as AB ELISA. EMA provided the $A \beta$ peptide and helped perform some $D C$ experiments with SA. SS provided reagents and helped write the manuscript. AA designed the study, analyzed the data, prepared the figures, and wrote the manuscript. All authors read and approved the final manuscript.

\section{Consent for publication}

The study was approved by the Institutional Review Board of the University of California, Irvine (UCI). Informed consent was obtained from the subjects.

\section{Competing interests}

The authors declare that they have no competing interests.

\section{Publisher's Note}

Springer Nature remains neutral with regard to jurisdictional claims in published maps and institutional affiliations.

\section{Author details California, Irvine, Irvine, CA 92697, USA. \\ Received: 12 March 2018 Accepted: 23 July 2018 \\ Published online: 16 August 2018}

'Division of Basic and Clinical Immunology, Department of Medicine, University of California, Irvine, Irvine, CA 92697, USA. ${ }^{2}$ UCI-MIND, University of

\section{References}

1. Richardson A, Galvan V, Lin AL, Oddo S. How longevity research can lead to therapies for Alzheimer's disease: the rapamycin story. Exp Gerontol. 2015;68:51-8.
2. Querfurth HW, LaFerla FM. Alzheimer's disease. N Engl J Med. 2010; 362(4):329-44.

3. Murphy MP, LeVine $H$ 3rd. Alzheimer's disease and the amyloid-beta peptide. J Alzheimers Dis. 2010;19(1):311-23.

4. Hyman BT, Phelps CH, Beach TG, Bigio EH, Cairns NJ, Carrillo MC, Dickson DW, Duyckaerts C, Frosch MP, Masliah E, et al. National Institute on AgingAlzheimer's Association guidelines for the neuropathologic assessment of Alzheimer's disease. Alzheimers Dement. 2012;8(1):1-13.

5. Montine TJ, Phelps CH, Beach TG, Bigio EH, Cairns NJ, Dickson DW, Duyckaerts C, Frosch MP, Masliah E, Mirra SS, et al. National Institute on Aging-Alzheimer's Association guidelines for the neuropathologic assessment of Alzheimer's disease: a practical approach. Acta Neuropathol. 2012:123(1):1-11.

6. Moore BD, Chakrabarty P, Levites Y, Kukar TL, Baine AM, Moroni T, Ladd TB, Das P, Dickson DW, Golde TE. Overlapping profiles of Abeta peptides in the Alzheimer's disease and pathological aging brains. Alzheimers Res Ther. 2012;4(3):18.

7. Li C, Gotz J. Tau-based therapies in neurodegeneration: opportunities and challenges. Nat Rev Drug Discov. 2017:16(12):863-83.

8. Moore S, Evans LD, Andersson T, Portelius E, Smith J, Dias TB, Saurat N, McGlade A, Kirwan P, Blennow K, et al. APP metabolism regulates tau proteostasis in human cerebral cortex neurons. Cell Rep. 2015;11(5):689-96.

9. Cai Z, Hussain MD, Yan L. Microglia, neuroinflammation, and beta-amyloid protein in Alzheimer's disease. Int J Neurosci. 2014;124(5):307-21.

10. McCaulley ME, Grush KA. Alzheimer's disease: exploring the role of inflammation and implications for treatment. Int J Alzheimers Dis. 2015;2015:515248.

11. Heppner FL, Ransohoff RM, Becher B. Immune attack: the role of inflammation in Alzheimer disease. Nat Rev Neurosci. 2015;16(6):358-72.

12. Heneka MT, Carson MJ, El Khoury J, Landreth GE, Brosseron F, Feinstein DL, Jacobs AH, Wyss-Coray T, Vitorica J, Ransohoff RM, et al. Neuroinflammation in Alzheimer's disease. Lancet Neurol. 2015;14(4):388-405.

13. Heneka MT, Golenbock DT, Latz E. Innate immunity in Alzheimer's disease. Nat Immunol. 2015;16(3):229-36.

14. Agrawal A, Agrawal S, Cao JN, Su H, Osann K, Gupta S. Altered innate immune functioning of dendritic cells in elderly humans: a role of phosphoinositide 3-kinase-signaling pathway. J Immunol. 2007;178(11):6912-22.

15. Agrawal A, Tay J, Ton S, Agrawal S, Gupta S. Increased reactivity of dendritic cells from aged subjects to self-antigen, the human DNA.J Immunol. 2009;182(2):1138-45

16. Agrawal S, Gollapudi S, Gupta S, Agrawal A. Dendritic cells from the elderly display an intrinsic defect in the production of IL-10 in response to lithium chloride. Exp Gerontol. 2013:48(11):1285-92.

17. Prakash S, Agrawal S, Vahed H, Ngyuen M, Benmohamad L, Gupta S, Agrawal A. Dendritic cells from aged subjects contribute to chronic airway inflammation by activating bronchial epithelial cells under steady state. Mucosal Immunol. 2014;7(6);1386-94.

18. Steinman RM. Decisions about dendritic cells: past, present, and future. Annu Rev Immunol. 2012;30:1-22.

19. Kaunzner UW, Miller MM, Gottfried-Blackmore A, Gal-Toth J, Felger JC, McEwen BS, Bulloch K. Accumulation of resident and peripheral dendritic cells in the aging CNS. Neurobiol Aging. 2012;33(4):681-93. e681

20. Agrawal A, Gupta S. Impact of aging on dendritic cell functions in humans. Ageing Res Rev. 2011;10(3):336-45.

21. Fulop T, Larbi A, Pawelec G. Human T cell aging and the impact of persistent viral infections. Front Immunol. 2013:4:271.

22. Le Saux S, Weyand CM, Goronzy JJ. Mechanisms of immunosenescence: lessons from models of accelerated immune aging. Ann N Y Acad Sci. 2012;1247:69-82.

23. Frasca D, Riley RL, Blomberg BB. Aging murine $B$ cells have decreased class switch induced by anti-CD40 or BAFF. Exp Gerontol. 2007;42(3):192-203.

24. Agrawal A, Su H, Chen J, Osann K, Agrawal S, Gupta S. Increased IL-21 secretion by aged CD4+ $T$ cells is associated with prolonged STAT-4 activation and CMV seropositivity. Aging (Albany NY). 2012;4(9):648-59.

25. Abud EM, Ramirez RN, Martinez ES, Healy LM, Nguyen CHH, Newman SA, Yeromin AV, Scarfone VM, Marsh SE, Fimbres C, et al. iPSC-derived human microglia-like cells to study neurological diseases. Neuron. 2017;94(2):278-93. e279

26. Qu BX, Gong Y, Moore C, Fu M, German DC, Chang LY, Rosenberg R, Diaz-Arrastia R. Beta-amyloid auto-antibodies are reduced in Alzheimer's disease. J Neuroimmunol. 2014;274(1-2):168-73.

27. Ciaramella A, Salani F, Bizzoni F, Orfei MD, Langella R, Angelucci F, Spalletta G, Taddei AR, Caltagirone C, Bossu P. The stimulation of dendritic cells by 
amyloid beta 1-42 reduces BDNF production in Alzheimer's disease patients. Brain Behav Immun. 2013;32:29-32.

28. Harold D, Jehu L, Turic D, Hollingworth P, Moore P, Summerhayes P, Moskvina V, Foy C, Archer N, Hamilton BA, et al. Interaction between the ADAM12 and SH3MD1 genes may confer susceptibility to late-onset Alzheimer's disease. Am J Med Genet B Neuropsychiatr Genet. 2007;144B(4):448-52.

29. Huang YP, Gauthey L, Michel M, Loreto M, Paccaud M, Pechere JC, Michel $J P$. The relationship between influenza vaccine-induced specific antibody responses and vaccine-induced nonspecific autoantibody responses in healthy older women. J Gerontol. 1992;47(2):M50-5.

30. Sarra M, Pallone F, Macdonald TT, Monteleone G. Targeting interleukin-21 in immune-mediated pathologies. Curr Drug Targets. 2010;1 1(5):645-9.

31. Ueno H, Banchereau J, Vinuesa CG. Pathophysiology of T follicular helper cells in humans and mice. Nat Immunol. 2015;16(2):142-52.

32. Mazure CM, Swendsen J. Sex differences in Alzheimer's disease and other dementias. Lancet Neurol. 2016;15(5):451-2.

33. Sochocka M, Diniz BS, Leszek J. Inflammatory response in the CNS: friend or foe? Mol Neurobiol. 2016;54(10):8071-89.

34. Ciaramella A, Bizzoni F, Salani F, Vanni D, Spalletta G, Sanarico N, Vendetti S, Caltagirone C, Bossu P. Increased pro-inflammatory response by dendritic cells from patients with Alzheimer's disease. J Alzheimers Dis. 2010;19(2):559-72.

35. Ciaramella A, Sanarico N, Bizzoni F, Moro ML, Salani F, Scapigliati G, Spalletta G, Caltagirone C, Bossu P. Amyloid beta peptide promotes differentiation of pro-inflammatory human myeloid dendritic cells. Neurobiol Aging. 2009;30(2):210-21.

36. Saresella M, Calabrese E, Marventano I, Piancone F, Gatti A, Calvo MG, Nemni R, Clerici M. PD1 negative and PD1 positive CD4+ T regulatory cells in mild cognitive impairment and Alzheimer's disease. J Alzheimers Dis. 2010;21(3):927-38

37. Baruch K, Rosenzweig N, Kertser A, Deczkowska A, Sharif AM, Spinrad A, Tsitsou-Kampeli A, Sarel A, Cahalon L, Schwartz M. Breaking immune tolerance by targeting Foxp3(+) regulatory T cells mitigates Alzheimer's disease pathology. Nat Commun. 2015;6:7967.

38. Ciaramella A, Salani F, Bizzoni F, Orfei MD, Caltagirone C, Spalletta G, Bossu P. Myeloid dendritic cells are decreased in peripheral blood of Alzheimer's disease patients in association with disease progression and severity of depressive symptoms. J Neuroinflammation. 2016;13(1):18.

39. Hunter S, Brayne C. Understanding the roles of mutations in the amyloid precursor protein in Alzheimer disease. Mol Psychiatry. 2018;23(1):81-93.

40. Delahaut P. Immunisation: choice of host, adjuvants and boosting schedules with emphasis on polyclonal antibody production. Methods. 2017;116:4-11.

41. Engels N, Wienands J. Memory control by the B cell antigen receptor. Immunol Rev. 2018;283(1):150-60.

42. Rajewsky K. Clonal selection and learning in the antibody system. Nature. 1996;381(6585):751-8.

43. Binder CJ, Hartvigsen $\mathrm{K}$, Chang MK, Miller M, Broide D, Palinski W, Curtiss LK, Corr M, Witztum JL. IL-5 links adaptive and natural immunity specific for epitopes of oxidized LDL and protects from atherosclerosis. J Clin Invest. 2004;114(3):427-37.

44. Chang MK, Binder CJ, Miller YI, Subbanagounder G, Silverman GJ, Berliner $J A$, Witztum JL. Apoptotic cells with oxidation-specific epitopes are immunogenic and proinflammatory. J Exp Med. 2004;200(11):1359-70.

45. Fiskesund R, Steen J, Amara K, Murray F, Szwajda A, Liu A, Douagi I, Malmstrom V, Frostegard J. Naturally occurring human phosphorylcholine antibodies are predominantly products of affinity-matured B cells in the adult. J Immunol. 2014;192(10):4551-9.

46. Marsh SE, Abud EM, Lakatos A, Karimzadeh A, Yeung ST, Davtyan H, Fote GM, Lau L, Weinger JG, Lane TE, et al. The adaptive immune system restrains Alzheimer's disease pathogenesis by modulating microglial function. Proc Natl Acad Sci U S A. 2016;113(9);E1316-1325.

47. Puli L, Tanila H, Relkin N. Intravenous immunoglobulins for Alzheimer's disease. Curr Alzheimer Res. 2014;11(7):626-36.

48. Spolski R, Leonard WJ. Interleukin-21: a double-edged sword with therapeutic potential. Nat Rev Drug Discov. 2014;13(5):379-95.

49. Zhang J, Ke KF, Liu Z, Qiu YH, Peng YP. Th17 cell-mediated neuroinflammation is involved in neurodegeneration of abeta1-42-induced Alzheimer's disease model rats. PLoS One. 2013;8(10):e75786.

50. Clarkson BD, Ling C, Shi Y, Harris MG, Rayasam A, Sun D, Salamat MS, Kuchroo V, Lambris JD, Sandor M, et al. T cell-derived interleukin (IL)-21 promotes brain injury following stroke in mice. J Exp Med. 2014;211(4):595-604.

Ready to submit your research? Choose BMC and benefit from:

- fast, convenient online submission

- thorough peer review by experienced researchers in your field

- rapid publication on acceptance

- support for research data, including large and complex data types

- gold Open Access which fosters wider collaboration and increased citations

- maximum visibility for your research: over $100 \mathrm{M}$ website views per year

At BMC, research is always in progress.

Learn more biomedcentral.com/submissions 